\title{
Diltiazem did not induce gingival overgrowth in rats. A clinical, histological and histometric analysis
}

\section{Diltiazem não induziu crescimento gengival em ratos. Análise clínica, histológica e histométrica}

\author{
Fernanda de Oliveira Bello Corrêa* \\ Gabriela Giro** \\ Daniela Gonçalves* \\ Luis Carlos Spolidorio*** \\ Silvana Regina Perez Orrico****
}

\begin{abstract}
The administration of calcium channel blockers has been associated with gingival overgrowth. However, there are few studies in humans or animals that evaluated the effect of diltiazem on gingival tissues. The present study assessed the influence of diltiazem, at different dosages and treatment duration, on gingival tissues of rats, using clinical, histological and histometric analyses. Eighty young male rats were separated into eight groups according to the dosage and duration of treatment. Rats were treated for 20 or 40 days with a daily subcutaneous injection of 5,20 or $50 \mathrm{mg} / \mathrm{kg}$ of body weight of diltiazem. The results confirmed that diltiazem did not induce gingival overgrowth in rats. For all animals, the evaluation did not show gingival alterations regardless of the dosages and periods of treatment. The histometric analysis showed no significant change in the area of epithelium and connective tissues, although after 40 days of treatment a decrease in the area of connective tissue was observed, without statistically significant difference from control groups. Within the limits of this study, we suggest that diltiazem did not induce gingival overgrowth.
\end{abstract}

DESCRIPTORS: Diltiazem; Antihypertensive agents; Gingival overgrowth.

\begin{abstract}
RESUMO: A administração de bloqueadores dos canais de cálcio tem sido associada com crescimento gengival; entretanto, existem poucos estudos em humanos e animais que avaliaram o efeito do diltiazem nos tecidos gengivais. O presente trabalho tem como objetivo avaliar o efeito do diltiazem, em diferentes dosagens e tempos de tratamento, no tecido gengival de ratos, por meio de análises clínica, histológica e histométrica. Oitenta ratos jovens machos foram divididos em oito grupos de acordo com a dosagem e o tempo de administração. Os animais foram tratados por 20 ou 40 dias com uma dosagem diária de diltiazem de 5,20 ou $50 \mathrm{mg} / \mathrm{kg}$ de peso corporal, por via subcutânea. Os resultados confirmaram que o diltiazem não induziu crescimento gengival em ratos. Para todos os animais a avaliação não demonstrou alterações gengivais, independentemente da dosagem e do período de tratamento. A análise histométrica evidenciou ausência de alteração significante na área de tecidos epitelial e conjuntivo, embora, após 40 dias de tratamento, tenha sido observada diminuição na área de tecido conjuntivo, não significante estatisticamente. Dentro dos limites deste estudo, sugerimos que o diltiazem não induziu crescimento gengival.

DESCRITORES: Diltiazem; Anti-hipertensivos; Crescimento excessivo da gengiva.
\end{abstract}

\section{INTRODUCTION}

It is well known that drugs (e.g. cyclosporin and calcium channel blockers) can cause gingival overgrowth in humans $\mathrm{s}^{3-6,10,14}$ and experimental animals ${ }^{7,9,12,13,22,24,28}$. Calcium channel blockers, antihypertensive drugs, are extensively used in elderly patients who have angina or peripheral vascular disease. Diltiazem specifically inhibits the penetration of calcium ions into the smooth vascular and cardiac muscle cells, promoting a decrease of the myocardial contraction force ${ }^{24}$.

The total number of annual prescriptions for this class of antihypertensive agent has increased in recent years. Gingival overgrowth associated with nifedipine was first reported in the early $1980 \mathrm{~s}^{17}$ and was later associated with verapamil ${ }^{21}$ and, in rare cases, with amlodipine ${ }^{8,15}$ and felodipine ${ }^{18,19}$.

\footnotetext{
* MScs, PhD Students of Periodontics, Department of Diagnosis and Surgery; **DDS, MSc Student of Periodontics, Department of Diagnosis and Surgery; ***PhD, Associate Professor of Oral Pathology, Department of Physiology and Pathology; **** PhD, Associate Professor of Periodontics, Department of Diagnosis and Surgery - School of Dentistry of Araraquara, São Paulo State University.
} 
Corrêa FOB, Giro G, Gonçalves D, Spolidorio LC, Orrico SRP. Diltiazem did not induce gingival overgrowth in rats. A clinical, histological and histometric analysis. Braz Oral Res 2005;19(3):163-8.

However, there are few studies in humans or animals that evaluate the effect of diltiazem on gingival tissues, including or not risk factors involved in the etiopathogenicity of this lesion ${ }^{10,12,14,23}$. The present study evaluated the effect of various dosages of diltiazem and its different administration periods on the induction or not of gingival overgrowth in rats.

\section{MATERIALS AND METHODS}

All animal care and study protocols were in compliance with the guidelines approved by the Animal Experiment Committee of the School of Dentistry of Araraquara, São Paulo State University.

Eighty Holtzman rats (Norvegicus albinus), weighing approximately $70 \mathrm{~g}$, were randomly distributed into eight groups of ten animals each. All the rats were housed under similar conditions and maintained on diet and water ad libitum. Two groups were used as control and received subcutaneous injection of saline solution (JP Indústria Farmacêutica, Ribeirão Preto, SP, Brazil) during the experimental periods. Six groups received diltiazem (Alcon Biosciences Pvt. Ltd., Mumbai, India) therapy. Diltiazem was injected subcutaneously, in a daily dose of 5,20 or $50 \mathrm{mg} / \mathrm{kg}$ of body weight for 20 or 40 days.

After the experimental periods, the rats were put down. Each mandible was carefully removed together with the surrounding gingival and soft tissue and soaked in 10\% formalin solution (Synth, Diadema, SP, Brazil).

\section{Clinical analysis}

A single blinded examiner using a magnifying glass evaluated whether any macroscopic characteristic of gingival overgrowth was present on the gingival tissue, such as an increase in volume of the marginal gingiva and interdental papilla.

After macroscopic observations, the mandibles were demineralized in Morse solution (Synth, Diadema, SP, Brazil) (50 $\mathrm{ml}$ of formic acid at $50 \%$ and $50 \mathrm{ml}$ of sodium citrate at $20 \%$ ) and changed every three days. Five-micrometer serial paraffin sections were made on the bucco-lingual aspects of the right first molars and stained with hematoxylin (Mallinckrodt Baker Inc., Paris, Kentucky, USA) and eosin (Nuclear, Diadema, SP, Brazil).

\section{Microscopic analysis}

Microscopic analysis was performed on the buccal gingiva of the lower first molars by the same single blinded examiner, using a light microscope BX51 (Olympus, Melville, New York, USA). Cell adhesion, number of cell layers and presence or not of deep papilla interdigitations were observed on the epithelial tissue; and the morphology of collagen fibers, cells and number of blood vessels were observed on the connective tissue.

\section{Histometry}

Ten measurements were made in sections of $60 \mu \mathrm{m}$ intervals on the buccal side of each marginal gingiva in the region of the lower first molar. The histometric analysis was performed using DIASTAR optical microscope (Leica Reichert \& Jung products, Wetzlar, Germany), object lens 10/0.25 (Leica Reichert \& Jung products, Wetzlar, Germany) and adapted video camera (Sony DXC - 107A, SONY Electronics Inc., Shinagawa-ku, Tokyo, Japan) connected to a computer. Gingival epithelium and connective tissue areas were measured with the Sigma Scan computer program (Mocha, Jandel Scientific, San Rafael, CA, USA). The areas were delineated by the end of the junctional epithelium. Statistical analysis was based on the mean value from each animal. Figure 1 shows the areas measured.

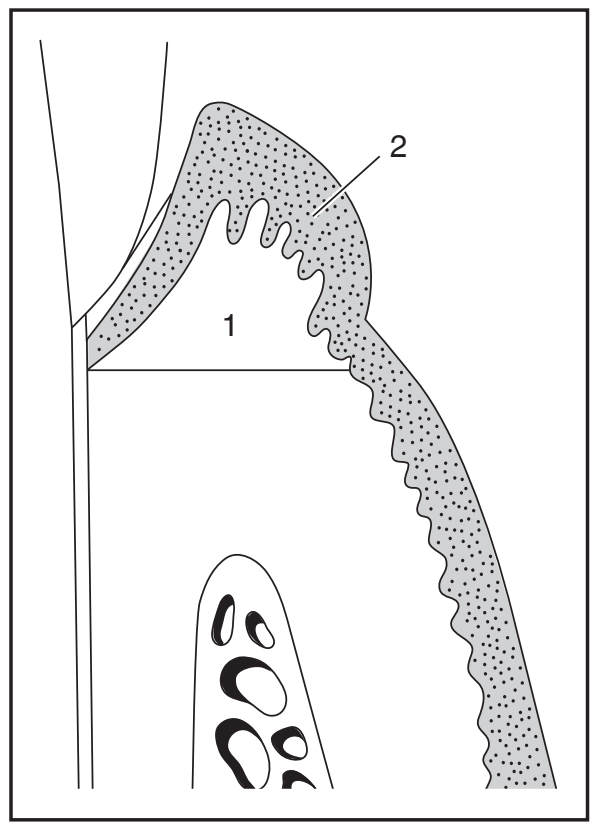

FIGURE 1 Identification of the sites for measurement of connective tissue (1) and epithelial areas (2) for each histological section. 
Corrêa FOB, Giro G, Gonçalves D, Spolidorio LC, Orrico SRP. Diltiazem did not induce gingival overgrowth in rats. A clinical, histological and histometric analysis. Braz Oral Res 2005;19(3):163-8.

\section{Statistical analysis}

Statistical evaluation of the histometric analysis was performed by one-way analysis of variance (ANOVA) using the dosage as a factor and by Student's $t$-test using the period as a factor. Effects were considered significant at $\mathrm{p}<0.05$.

\section{RESULTS}

\section{Macroscopic and microscopic data}

All animals survived the experimental periods. All rats treated with diltiazem did not present any alterations in body mass, regardless of the dose and duration of treatment, in comparison with control groups $(\mathrm{p}=0.455)$.

The macroscopic analysis of the lower molar gingiva of rats in both control and experimental groups, in the buccal and lingual regions, presented similar clinical aspects. The gingiva surrounded the cervical portion of the teeth, ending in a tapered form. It also had clear papillae between all the lower molars.

In addition, no microscopic alterations in the gingival tissues were observed, regardless of the treatment. In all groups, the epithelium presented 3-5 layers of cells without hyperplasia or deep papilla interdigitations and the connective tissue presented normal quantity of collagen fibers, some macrophages or plasma cells and normal blood vessels.

\section{Histometry}

Table 1 shows the results of one-way ANOVA, used to evaluate the effect of the different dosages (control, 5, 20 and $50 \mathrm{mg} / \mathrm{kg}$ ) of diltiazem administration on the connective and epithelial tissue areas. No significant difference was observed between the mean values of connective and epithelium tissue areas when all the different dosages were compared in each period of treatment $(\mathrm{p}>0.05)$.

Table 2 shows the results of the Student's $t$ test, used to assess the effect of treatment duration (20 and 40 days) on the connective and epithelial tissue areas. No statistically significant difference was observed between the mean values of connective and epithelium tissue areas when both periods were compared with each different dosage of diltiazem $(\mathrm{p}>0.05)$.
TABLE 1 - Histometric analysis of the influence of different doses of the drug on the connective tissue area (A1) and the epithelial tissue area (A2) of the lower first molar buccal gingiva $(n=10)$.

\begin{tabular}{|c|c|c|c|c|}
\hline Area & $\begin{array}{l}\text { Period } \\
\text { (days) }\end{array}$ & $\begin{array}{c}\text { Dose } \\
(\mathrm{mg} / \mathrm{kg})\end{array}$ & $\begin{array}{c}\text { Mean } \pm \text { SD } \\
\left(\mathrm{mm}^{2}\right)\end{array}$ & $\begin{array}{l}\text { ANOVA } \\
\text { test }\end{array}$ \\
\hline \multirow{4}{*}{ A1 } & \multirow{4}{*}{20} & Control & $21.78 \pm 9.61$ & \multirow{4}{*}{$\mathrm{p}=0.550$} \\
\hline & & 5 & $17.64 \pm 8.85$ & \\
\hline & & 20 & $16.66 \pm 5.30$ & \\
\hline & & 50 & $19.96 \pm 6.08$ & \\
\hline \multirow{4}{*}{ A2 } & \multirow{4}{*}{20} & Control & $31.78 \pm 9.57$ & \multirow{4}{*}{$p=0.697$} \\
\hline & & 5 & $27.90 \pm 6.93$ & \\
\hline & & 20 & $27.47 \pm 7.79$ & \\
\hline & & 50 & $30.55 \pm 6.83$ & \\
\hline \multirow{4}{*}{$\mathrm{A} 1$} & \multirow{4}{*}{40} & Control & $16.04 \pm 3.54$ & \multirow{4}{*}{$\mathrm{p}=0.192$} \\
\hline & & 5 & $12.71 \pm 3.54$ & \\
\hline & & 20 & $17.48 \pm 6.82$ & \\
\hline & & 50 & $17.65 \pm 7.51$ & \\
\hline \multirow{4}{*}{$\mathrm{A} 2$} & \multirow{4}{*}{40} & Control & $34.83 \pm 4.69$ & \multirow{4}{*}{$\mathrm{p}=0.211$} \\
\hline & & 5 & $27.24 \pm 11.13$ & \\
\hline & & 20 & $32.64 \pm 7.40$ & \\
\hline & & 50 & $29.41 \pm 9.36$ & \\
\hline
\end{tabular}

TABLE 2 - Histometric analysis of the influence of periods of administration on the connective tissue area (A1) and the epithelial tissue area (A2) of the lower first molar buccal gingiva $(\mathrm{n}=10)$.

\begin{tabular}{|c|c|c|c|c|}
\hline Area & $\begin{array}{c}\text { Dose } \\
(\mathrm{mg} / \mathrm{kg})\end{array}$ & $\begin{array}{c}\text { Period } \\
\text { (days) }\end{array}$ & $\begin{array}{l}\text { Mean } \pm \text { SD } \\
\left(\mathrm{mm}^{2}\right)\end{array}$ & $\begin{array}{c}\text { Student's } \\
t \text {-test }\end{array}$ \\
\hline \multirow{8}{*}{ A 1} & \multirow{2}{*}{ Control } & 20 & $21.78 \pm 9.61$ & \multirow{2}{*}{$\mathrm{p}=0.102$} \\
\hline & & 40 & $16.04 \pm 3.54$ & \\
\hline & \multirow{2}{*}{5} & 20 & $17.64 \pm 8.85$ & \multirow{2}{*}{$\mathrm{p}=0.131$} \\
\hline & & 40 & $12.71 \pm 3.54$ & \\
\hline & \multirow{2}{*}{20} & 20 & $16.66 \pm 5.30$ & \multirow{2}{*}{$p=0.765$} \\
\hline & & 40 & $17.48 \pm 6.82$ & \\
\hline & \multirow{2}{*}{50} & 20 & $19.96 \pm 6.08$ & \multirow{2}{*}{$p=0.459$} \\
\hline & & 40 & $17.65 \pm 7.51$ & \\
\hline \multirow{8}{*}{ A2 } & \multirow{2}{*}{ Control } & 20 & $31.78 \pm 9.57$ & \multirow{2}{*}{$\mathrm{p}=0.381$} \\
\hline & & 40 & $34.83 \pm 4.69$ & \\
\hline & \multirow{2}{*}{5} & 20 & $27.90 \pm 6.93$ & \multirow{2}{*}{$\mathrm{p}=0.874$} \\
\hline & & 40 & $27.24 \pm 11.13$ & \\
\hline & \multirow{2}{*}{20} & 20 & $27.47 \pm 7.79$ & \multirow{2}{*}{$p=0.146$} \\
\hline & & 40 & $32.64 \pm 7.40$ & \\
\hline & \multirow{2}{*}{50} & 20 & $30.55 \pm 6.83$ & \multirow{2}{*}{$\mathrm{p}=0.760$} \\
\hline & & 40 & $29.41 \pm 9.36$ & \\
\hline
\end{tabular}


Corrêa FOB, Giro G, Gonçalves D, Spolidorio LC, Orrico SRP. Diltiazem did not induce gingival overgrowth in rats. A clinical, histological and histometric analysis. Braz Oral Res 2005;19(3):163-8.

\section{DISCUSSION}

Rats have been used extensively to study the effects of drugs on the gingiva, and their tissue overgrowth is similar to that of humans. Moreover, the rat model is convenient because the animals are small, inexpensive and easy to care for ${ }^{28}$. In fact, response in rats is more uniform than that in humans, and many variables are better controlled, such as genetic predisposition, gender, age, dose and duration of treatment ${ }^{16}$.

With respect to the growth of rats, it was noted that diltiazem did not affect their weight gain, which is in agreement with the findings of Morisaki et al. ${ }^{23}$ (1993), Ishida et al. ${ }^{13}$ (1995), Fu et al. ${ }^{9}$ (1998), and Morisaki et al. ${ }^{22}$ (2000).

Concerning the clinical aspect, it is known that gingival overgrowth in humans occurs with generalized gingival increase, which is lobulated, with probable interdental origin, also involving the gingival attachment, and is more pronounced in the anterior buccal and lingual region ${ }^{1,4,5,8,10,11,18,20}$. In animals, Fu et al. ${ }^{9}$ (1998) found that the administration of nifedipine resulted in significant increase in the gingival dimensions (buccallingual width, mesiodistal width and vertical height), depending upon the dosage and duration of treatment. Similarly, Spolidorio et al. ${ }^{28}$ (2002), while performing macroscopic and microscopic evaluations of the gingival morphology in rats treated with nifedipine and/or cyclosporine, observed significant gingival overgrowth. However, in the present study, none of the animals presented macroscopic gingival overgrowth.

Histological evaluation in this study showed that the gingival tissue of the experimental groups (treated with diltiazem) presented normal characteristics, similar to that of control groups. Nevertheless, other authors ${ }^{2,3,6,10}$ evaluated the gingival tissue of humans treated with diltiazem and observed the presence of histological characteristics such as the presence of increased epithelium with parakeratosis, acanthosis and elongated rete pegs. In relation to the connective tissue, the studies evidenced bundles of collagen fibers and a fundamental substance presenting a large quantity of glycosaminoglycans, an increased number of fibroblasts, vascularization and moderate inflammatory reaction with presence of lymphocytes and plasma cells surrounding the vessels ${ }^{1,17,18,21,26,27}$.

Considering the time factor, according to Nishikawa et al. ${ }^{25}$ (1996), the minimum period of drug administration for gingival overgrowth visual- ization induced by phenytoin, cyclosporine and/or nifedipine is 20 days, tending towards stabilization after 40 days. Therefore, this study evaluated the influence of various diltiazem concentrations after 20 and 40 days of administration.

The result of the histometric analysis showed that the periods of 20 or 40 days were not sufficient to induce gingival growth for any of the diltiazem concentrations studied (Table 2). On the other hand, Morisaki et al. ${ }^{22}$ (2000) observed significant gingival overgrowth in rats that received $1,000 \mu \mathrm{g} /$ $\mathrm{g}$ of diltiazem for 10 days $+6,000 \mu \mathrm{g} / \mathrm{g}$ of diltiazem in their diet during 30 days, reaching a plasma concentration of the drug of $19.8 \mathrm{ng} / \mathrm{ml}$.

The findings of Morisaki et al..$^{22}$ (2000) contradict the results of this study. However, it should be highlighted that the method of diltiazem administration, as well as its concentration, were different, since the mentioned author assessed much larger dosages.

Furthermore, duration of drug administration necessary for macroscopic visualization of gingival tissue alteration varies considerably according to the type of medicine. For rats, Nishikawa et al. ${ }^{25}$ (1996) demonstrated that the minimum time for visualization of gingival overgrowth induced by cyclosporine and phenytoin or nifedipine is 20 days. Nyska et al. ${ }^{27}$ (1990) established a period of eight to nine months as the minimum time for inducing macroscopic gingival alterations in rats treated with oxodipine.

To evaluate the effect of different diltiazem concentrations, the animals were separated into four groups $(0,5,20$ and $50 \mathrm{mg} / \mathrm{kg})$. Admitting that a dose of $5 \mathrm{mg} / \mathrm{kg}$ corresponds to the average intake of an adult with hypertension, larger doses were used to assess the influence of dose increase on the gingival tissue, according to experimental protocols used in other studies that evaluated gingival overgrowth induced by nifedipine $^{7,9,12,13,22,23,28}$.

The present study demonstrated no significant difference between groups for the connective and epithelium tissue areas, neither when different doses $(5,20,50 \mathrm{mg} / \mathrm{kg})$ of diltiazem were used (Table 1), nor when both periods of treatment $(20$ and 40 days) were evaluated with each different dosage (Table 2), suggesting that the drug concentration and treatment duration did not influence gingival alteration.

On the other hand, Fu et al. ${ }^{9}$ (1998) demonstrated that gingival overgrowth induced by nifedipine was influenced by drug concentration ad- 
Corrêa FOB, Giro G, Gonçalves D, Spolidorio LC, Orrico SRP. Diltiazem did not induce gingival overgrowth in rats. A clinical, histological and histometric analysis. Braz Oral Res 2005;19(3):163-8.

ministered in the diet. The group that received $50 \mathrm{mg} / \mathrm{kg}$ of nifedipine increased gingival dimensions when compared with the group that received only $30 \mathrm{mg} / \mathrm{kg}$ of it or with the control group. In addition, Ishida et al. ${ }^{13}$ (1995) observed that the concentration of nifedipine administered in the diet can influence the concentration of the drug found in blood plasma. It was proven that plasma drug concentration in male rats with gingival overgrowth was lower than that in females, which also presented this alteration; this shows that the use of male rats is more promising. For this reason, drug concentration in blood plasma may be an important factor to set off gingival alterations.

Although in this study no gingival overgrowth induced by diltiazem in rats was observed, other studies should be carried out to understand if larger concentrations of the drug or longer periods of drug administration might cause gingival alteration.

It must be highlighted that hypertension is now considered a public health problem and that the incidence of young patients with this alteration is rising rapidly throughout the world. Consid-

\section{REFERENCES}

1. Akimoto Y, Tanaka S, Omata H, Shibutani J, Nakano Y, Kaneko K, et al. Gingival hyperplasia induced by nifedipine. J Nihon Univ Sch Dent 1991;33(3):174-81.

2. Bowman JM, Levy BA, Grubb RV. Gingival overgrowth induced by diltiazem. Oral Surg Oral Med Oral Pathol 1988;65(2):183-5.

3. Bullon P, Machuca G, Armas JR, Rojas JL, Jiménez G. The gingival inflammatory infiltrate in cardiac patients treated with calcium antagonists. J Clin Periodontol 2001;29:897-903.

4. Bullon P, Machuca G, Martinez-Sahuquillo A, Rios JV, Velasco E, Rojas J, et al. Evaluation of gingival and periodontal conditions following causal periodontal treatment in patients treated with nifedipine and diltiazem. J Clin Periodontol 1996;23(7):649-57.

5. Bullon P, Machuca G, Martinez-Sahuquillo A, Rojas J, Lacalle JR, Rios JV, et al. Clinical assessment of gingival size among patients treated with diltiazem. Oral Surg Oral Med Oral Pathol Oral Radiol Endod 1995;79(3):300-4.

6. Bullon P, Pugnaloni A, Gallardo I, Machuca G, Hevia A, Battino M. Ultrastructure of the gingiva in cardiac patients treated with or without calcium channel blockers. J Clin Periodontol 2003;30(8):682-90.

7. Chiu HC, Fu E, Chiang C, Liu D. Does nifedipine aggravate cyclosporin-induced gingival overgrowth? An experiment in rats. J Periodontol 2001;72(4):532-7.

8. Ellis JS, Seymour RA, Steele JG, Robertson P, Butler TJ, Thomason JM. Prevalence of gingival overgrowth induced by calcium channel blockers: a community-based study. J Periodontol 1999;70:63-7. ering the lack of studies with other medications widely used as calcium channel blockers and taking into account that specific literature emphasizes eventual occurrence of this gingival alteration only with nifedipine, further research is necessary for possible detection of adverse effects in the oral cavity.

\section{CONCLUSION}

In conclusion, within the limits of this study, diltiazem did not influence the growth of the animals and did not induce gingival overgrowth in the rats treated with different dosages of diltiazem for 20 and 40 days, suggesting that the factors dosage and treatment duration did not influence in the induction of gingival alteration.

\section{ACKNOWLEDGMENTS}

This study was supported in part by grants from the Coordination for the Improvement of Higher Education Personnel (CAPES).

9. Fu E, Nieh S, Hsiao CT, Hsieh Y, Wikesjo UME, Shen E. Nifedipine-induced gingival overgrowth in rats: brief review and experimental study. J Periodontol 1998;69(7):765-71.

10. Giustiniani S, Della Cuna FR, Marieni F. Hyperplastic gingivitis during diltiazem therapy. Int $\mathrm{J}$ Cardiol $1987 ; 15(2): 247-9$.

11. Hancock RH, Swan RH. Nifedipine-induced gingival overgrowth. J Clin Periodontol 1992;19(1):12-4.

12. Heijl L, Sundin Y. Nitrendipine-induced gingival overgrowth in dogs. J Periodontol 1988;60(2):104-12.

13. Ishida $\mathrm{H}$, Kondoh $\mathrm{T}$, Kataoka M, Nishikawa S, Nakagawa T, Morisaki I, et al. Factors influencing nifedipine-induced gingival overgrowth in rats. J Periodontol 1995;66(5):345-50.

14. James JA, Marley JJ, Jamal S, Campbell BA, Short $\mathrm{CD}$, Johnson RW, et al. The calcium channel blocker used with cyclosporin has an effect on gingival overgrowth. J Clin Periodontol 2000;27(2):109-15.

15. Jorgensen MG. Prevalence of amlodipine-related gingival hyperplasia. J Periodontol 1997;68(7):676-8.

16. Kataoka M, Shimizu Y, Kunikiyo K, Asahara Y, Yamashita K, Ninomiya $\mathrm{M}$, et al. Cyclosporin A decreases the degradation of type I collagen in rat gingival overgrowth. J Cell Physiol 2000;182:351-8.

17. Lederman D, Lumerman H, Reuben S, Freedman PD. Gingival hyperplasia associated with nifedipine therapy. Oral Surg Oral Med Oral Pathol 1984;57(6):620-2.

18. Lombardi T, Fiore-Donno G, Belser U, Di Felice R. Felodipine-induced gingival hyperplasia: a clinical and histologic study. J Oral Pathol Med 1991;20(2):89-92.

19. Marshal RI, Bartold PM. A clinical review of drug-induced gingival overgrowths. Aust Dent J 1999;44(4):219-32. 
Corrêa FOB, Giro G, Gonçalves D, Spolidorio LC, Orrico SRP. Diltiazem did not induce gingival overgrowth in rats. A clinical, histological and histometric analysis. Braz Oral Res 2005;19(3):163-8.

20. McKevitt KMB, Irwin CR. Phenotypic differences in growth, matrix synthesis and response to nifedipine between fibroblasts derived from clinically healthy and overgrown gingival tissue. J Oral Pathol Med 1995;24(2):66-71.

21. Miller CS, Damm DD. Incidence of verapamil-induced gingival hyperplasia in a dental population. J Periodontol 1992;63(5):453-6.

22. Morisaki I, Fukui N, Fujimori Y, Murakami J, Daikoku H, Amano A. Effects of combined oral treatments with cyclosporine $\mathrm{A}$ and nifedipine or diltiazem on drug-induced gingival overgrowth in rats. J Periodontol 2000;71(3):438-43.

23. Morisaki I, Kato K, Loyola-Rodriguez JP, Nagata T, Ishida $\mathrm{H}$. Nifedipine-induced gingival overgrowth in the presence or absence of gingival inflammation in rats. $\mathrm{J}$ Periodontal Res 1993;28(6):396-403.

24. Murad, F. Drugs used for the treatment of angina: organic nitrate, calcium channel blockers and beta-ad- renergic antagonists. In: Gilman AG, Rall TW, Nies AS, Taylor P. Goodman \& Gilman's The Pharmacological Basis of Therapeutics. $8^{\text {th }}$ ed. New York: Pergamon Press; 1990. p. 764-83.

25. Nishikawa S, Nagata T, Morisaki I, Oka T, Ishida H. Pathogenesis of drug-induced gingival overgrowth. A review of studies in the rat model. J Periodontol 1996;67(5):463-71.

26. Nishikawa S, Tada H, Hamasaki A, Kasahara S, Kido $\mathrm{J}$, Nagata $\mathrm{T}$, et al. Nifedipine-induced gingival hyperplasia. A clinical and in vitro study. J Periodontol 1991;62:30-5.

27. Nyska A, Waner T, Pirak M, Galiano A, Zlotogorski A. Gingival hyperplasia in rats induced by oxodipine - a calcium channel blocker. J Periodontal Res 1990;25(2):65-8.

28. Spolidorio LC, Spolidorio DM, Neves KA, Gonzaga HFS, Almeida OP. Morphological evaluation of combined effects of cyclosporin and nifedipine on gingival overgrowth in rats. J Periodontal Res 2002;37:192-5.

Received for publication on Apr 08, 2005

Sent for alterations on May 11, 2005

Accepted for publication on Jul 04, 2005 